\title{
A Place to Breathe in the Dense City: Community Gardening and Participatory Urbanism in Paris ${ }^{1}$
}

\author{
Carrie Ann Benjamin
}

\begin{abstract}
Community gardens have emerged in Paris as a way to create green spaces in the city's densely populated working-class neighbourhoods. One such garden is the Goutte Verte, a temporary, nomadic community garden that, with the agreement of the city and its developers, occupies vacant lots awaiting the construction of new-build social housing. The continued existence of the Goutte Verte is placed in opposition to much-needed housing in the city, with poor, unemployed, and middle-class gardeners alike caught between a desire for green space and a demand for comfortable housing. Drawing on participant observation and interviews conducted in 2013-14 and 2019, I demonstrate how community gardens act as a material alternative to urban planning and governance that often fail to account for a right to a "place to breathe" in the city - a situation that is increasingly fraught as city planners treat new construction as the primary solution for affordable housing in Paris.
\end{abstract}

KEYWORDS urban, community gardens, housing, green space, Paris

In recent years, Henri Lefebvre's theory of the right to the city has been subject to revision as sociologists and geographers grapple with its over-use and question its applicability in the 21st-century. While some scholars have presented case studies of food security, community gardens, and green spaces as a demand to the right to the city (Purcell and Tyman 2015; Shillington 2013), others have noted that such research risks falling into the "local trap" (Purcell 2006) by romanticizing localized interventions, campaigns, and democracy rather than focusing on the way urban struggles are imbricated with wider regional and global processes. This has led to calls for scholarship to "theorize beyond" (Uitermark, Nicholls and Loopmans 2012) the "vague" (Yiftachel 2015) concept of the right to the city. While some of these critiques have been used to translate the radical vision of the right to the city into a policy-oriented approach (Duke 2009; Pierce, Williams and Martin 2016; Purcell 2014), others have highlighted the shortcomings of over-applying the right to the city framework, particularly when one group's right results in the denial of another's (Attoh 2011; Blokland et al. 2015). While there has been much written about where and how people demand a right to the city, Lefebvre's emphasis on the urban as an oeuvre, which is foundational

Sociální studia / Social Studies 1/2020. Pp. 55-70. ISSN 1214-813X.

1 The research for this article was supported by a Leverhulme Trust Early Career Fellowship. I would like to thank the editors and the two anonymous reviewers for their helpful comments and feedback on an earlier draft of this article. 
to understanding the role of struggle and appropriation in this demand to urban life, has sometimes been downplayed. Instead, reframing a Lefebvrian approach to focus on the roles of inhabitants in creating the urban oeuvre through appropriating and self-managing the spaces of the city, as well the impact of urban planning on restricting urban life, can permit us to explore localized case studies without getting caught up in whether or not they represent a "demand" to the right to the city (Purcell 2014).

As the most densely populated city in Europe, Paris offers an interesting case study on how inhabitants both appropriate city spaces and voids as well as confront urban planning that seeks to restrict this right. In recent years, residents have appropriated vacant lots in the northern and eastern parts of city to form community gardens as a way to address the lack of green spaces and to create new places for community interaction (Demailly and Darly 2017). In the Goutte d'Or neighbourhood, the city government has facilitated these interventions, encouraging local residents to occupy vacant lots awaiting new-build social housing construction through top-down participatory frameworks and formal contracts for nomadic or temporary gardens. However, this form of "participation from above" (Cupers 2014) places restrictions on how and for how long residents can appropriate spaces, making their role in producing the urban oeuvre contingent on agreeing to the city's terms and conditions and accepting their eventual displacement for new housing construction. In the sections that follow, I explore Lefebvre's emphasis on inhabitants' participation in urban life and the complementary nature of housing and green spaces for accessing a "human and humane life" (Marcuse 2012: 31). Then I present the role of community gardens in providing access to green space in densely-populated Paris, where responses to the housing crisis have focused primarily on new-build social housing. Using the case of the Goutte Verte (Green Drop), a nomadic community garden in the Goutte d'Or neighbourhood in Paris's $18^{\text {th }}$ arrondissement (council), I demonstrate the impact that green spaces have on marginalized residents' quality of life and on their connection to the neighbourhood, and the disappointments that result from an artificial form of top-down participatory urbanism. While nomadic gardens offer a temporary alternative to urban planning that fails to account for a "place to breathe" in densely-populated Paris, residents' occupation of open, vacant land places them in opposition to housing development, particularly when new-build housing is presented as the primary solution for affordable accommodation. I argue that by forcing this unnecessary conflict between housing and green space, city planners ignore the role that both play in a "humane" and just city and hence deny marginalized inhabitants' full participation in urban life.

\section{Methodology}

This article draws upon a larger, ongoing ethnographic study of gentrification and public space in Paris. The data presented below were collected through participant observation in community gardens and green spaces in northern Paris in 2013-2014 and 2019, and through semi-structured, group, and walking interviews with 12 garden members and visitors. In 2013-2014 I was an active member of the Goutte Verte, a community garden in the Goutte d'Or neighbourhood with a diverse membership of 50 individuals. The garden was one 
of dozens of local associations invested in "social cohesion" and improving the quality of life in the neighbourhood, and it grew on vacant lots awaiting construction through an agreement with the city's semi-public developer SEMAVIP. I helped to tend the communal plots, organized and assisted during parties, participated in group meetings, prepared and shared communal meals with other gardeners, and eventually tended to my own one-square-meter parcel of land. My continuous engagement with the everyday maintenance and activity of the garden, particularly during the quiet and cold winter months, brought me into contact with the diverse membership of the garden and, at times, threw me into the changing landscape of rivalries and conflicts that often emerged over communication, power, and land access (Demailly 2014).

Interlocutors were selected through "snowball sampling" among the most active members. Interviews were conducted in French and English, and took place in the garden, sometimes amongst other gardeners and at other times in quiet periods where no one else was around. A few interviews took place in interlocutors' homes, in local cafes, or as mobile, walking interviews with interlocutors leading me through familiar parts of their neighbourhood and letting the spaces and sites provide a catalyst for our discussions. Informal discussions whilst sitting around the garden during the spring and summer months also yielded fruitful information and insights into the relationships that gardeners formed with and within the Goutte Verte. I also attended numerous town hall meetings, neighbourhood councils and public consultations in 2013, 2014, and 2019 relating to security, green spaces, regeneration projects, and social housing provisions in the $18^{\text {th }}$ arrondissement. This was supplemented with archival and documentary research, including the official minutes of city council meetings, construction and demolition permits, official SEMAVIP documents and reports, and local association archives (including periodicals, flyers and blog posts). In line with standard practices in social anthropological research, the data analysis was contextual and "flexible" rather than applying one particular framework, relying on "working deeply" with fieldnotes, archival documents, interviews and my own personal reflections to highlight broader themes that "emerged" (Boellstorff et al. 2012: 159). Overall, the data provide both a representative depiction of the role of the Goutte Verte in the lives of members during its longest occupation and insight into the tensions that persist between the need for housing and the desire for green space in one of Paris's most densely populated neighbourhoods.

\section{Theoretical Framing}

\section{Urban Planning and the Oeuvre}

Lefebvre (2000) conceptualizes the urban as an oeuvre, a work of art that is produced by its inhabitants through their social relations, appropriation of city spaces, and everyday lives. The oeuvre is central to understanding his formulation of the right to the city, which is defined by the right of inhabitants to actively participate in the remaking of their city, the production of urban life, and hence the remaking of global and rural-urban relationships. At its foundation, the right to the city is a "cry and demand" for a "renewed right to urban 
life" (Lefebvre 2000: 158) and "a right to change ourselves by changing the city" (Harvey 2008: 23) through appropriating and self-managing city spaces (Butler 2012). Lefebvre identifies the "voids" in the city - the chasms, holes and monumental open spaces - as having the greatest potential for appropriation, reclamation, and self-management by inhabitants. Referring to these voids as "the places of the possible" (2000: 156), he presents them as the sites where inhabitants can construct alternatives to privatization and capital accumulation from the ground-up. It is through the appropriation and self-management of these voids and spaces of the city that inhabitants can subvert state power and contribute to the artistic production of the urban as oeuvre.

However, not all appropriations result in a demand for the right to the city. Instead, it is through the participation of all "social groups and the whole society" (Lefebvre 2003: 100) that urban life as a work of art is produced. This has led many scholars to argue that democratizing urban planning and governance can increase the participation of inhabitants in urban life and hence strengthen their claim to the right to the city (Chaskin and Joseph 2013; Duke 2009). Yet democratization can also have the opposite effect by excluding a marginalized minority from public spaces and city life (Attoh 2011; Mitchell 2003). Indeed, top-down state attempts to democratize urban planning can both amplify the voices and opinions of the powerful while removing any possibility of self-management by residents. The French state in particular has attempted to create a form of participatory urbanism from above, focusing on the inclusion of experts and "representative" associations in urban planning to the detriment of direct resident participation (Cupers 2014; Donzelot 2003). This form of top-down participatory urbanism has been labelled a "charade" (Butler 2012: 146) that makes it possible for city planners to manipulate, control, and exclude inhabitants. If the right to the city entails "the right not to be marginalized in decision-making" or to not be forced into or out of certain decision-making processes (McCann 2002: 78), then public consultations on top-down urban projects effectively deny inhabitants full participation by denying self-management (Lefebvre 1976). Thus, while the urban is an oeuvre produced by the city's inhabitants, it is also the product of confrontation by the people with top-down city planning that attempts to control urban life on its terms.

\section{Gardens, Housing and the Right to the City}

Creating urban community gardens has become a popular method for appropriating and selfmanaging city spaces and contributing to the oeuvre of urban life. They have been used to improve access to green spaces and fresh food and to facilitate community cooperation and participation by offering an alternative to commodified top-down urbanism and privatization (Eizenberg 2012). Gardeners may find a sense of belonging, connection, and ownership in their neighbourhoods through community gardening, particularly in low-income renter-occupied areas where people may live in precarious situations and where fresh produce and city services are limited (Eizenberg 2013). As poor households and elderly residents who lack access to private gardens stand to benefit from greater provision of and access to green spaces in general (Barbosa et al. 2007), urban gardens offer a compelling example of how the struggle for the right to the city is taking place in some cities (Purcell and Tyman 2015). 
Nevertheless, by appropriating the vacant spaces of the city, community gardens have also been pitted against housing in a contrived conflict between the needs and aspirations of inhabitants. This has been well documented in New York City, where the community gardens that emerged on inner-city lots left vacant following the 1970s financial crisis became a barrier to investment and construction when the city began to re-appropriate land in these districts. Community gardens were initially treated by NYC developers as prime sites for building low-income or middle-income housing, which created tension between housing rights activists and gardeners, particularly as many gardeners were also activists in need of low-income housing (Schmelzkopf 1995). The city began to portray housing as a "public good", depicting the community gardens as obstacles to better housing provision, even though construction plans focused on middle-class households and the sale of vacant lots made no stipulation about how the land could be used by developers (Staeheli, Mitchell and Gibson 2002). This forced an unnecessary conflict between marginalized residents in need of housing and those disillusioned inhabitants who aspired to a city transformed through gardening - an artificial distinction and oversimplification that ignored the overlap between the two groups and the complementary role of gardens and housing (Smith and Kurtz 2003). Such distinctions pit the "demands of the deprived" against the "aspirations of the alienated", ignoring the fact that the need for housing and the desire for green space may both be necessary for "a human and humane life" (Marcuse 2012: 31).

However, there has been a tendency by urban scholars to celebrate gardens and green spaces as an inherent "good" in contrast to the "unnatural" concrete city (Classens 2015). In fact, green spaces can be used to control access to and use of public spaces (Ward Thompson 2012) or to isolate communities and segregate populations (Mancebo 2015). As plans for green spaces in Paris are often included in top-down projects with superficial "participatory" measures built in, the plans may fail to account for inhabitants "needs, desires, and definitions of what a 'good environment' is" (Mancebo 2015: 280-281). Creating or preserving urban green spaces, while linked to issues of environmental justice, may also affect property values, displace households, and hinder access to the commons for all but the wealthiest (Harvey 2012; Wolch, Byrne, and Newell 2014). Thus, an increased quantity of green space does not necessarily equate to an improved quality of life; areas with access to nature and parks may be undesirable or inaccessible due to physical, social, or economic segregation while densely populated areas with few trees may still offer inhabitants a high quality of life. Rather, the needs and desires of inhabitants must be the foundation for any form of "humane" urbanism, one that allows for creative appropriation, production, and self-management of spaces from the ground up (Purcell 2003: 103).

\section{Green Spaces and Housing: The Parisian Context}

Paris is the most densely populated city in Europe, and its northern and eastern neighbourhoods are amongst the most densely populated areas in the European Union (EUROSTAT 2016). This density maps onto the working-class neighbourhoods of the $18^{\text {th }}, 19^{\text {th }}$, and $20^{\text {th }}$ arrondissements where social housing construction has been concentrated since the 1980s. Amongst the most densely populated neighbourhoods is the Goutte d'Or, a working-class migrant area, with 
a population density of 568 people per hectare, more than twice the Parisian average of 211 per hectare (APUR 2019). This persists despite over 30 years of urban renewal projects that have demolished the neighbourhood's dilapidated and cramped housing and replaced it with larger, new-build social housing aimed at improving living conditions, reducing population density, and bringing in middle-class households to create a social mix $^{2}$ (Bacqué and Fijalkow 2012). While social housing for the middle classes has increased - often at the expense of poorer households that have been relocated outside the area - crowded private rental accommodations persist, meaning that the area remains densely populated with a lower-than-average quality of housing for the city (Fijalkow 2013).

While population density in Paris remains high, the number of vacant properties is growing and contributing to the housing crisis. Between 2011 and 2016, the number of vacant properties (excluding second homes and vacation rentals) in the $18^{\text {th }}$ arrondissement increased from 9,342 , or $7.7 \%$ of the total number of properties, to $10,193(8.4 \%)$, despite the creation of nearly 500 new properties during that same period (INSEE 2019). Along with this reduction in the number of homes available to residents, the cost of living in Paris has been rising steadily, with many of the city's poorest households pushed outside the capital (see Clerval 2013). In 2017 there were 187,286 people on the waiting list for social housing in Paris (OLS 2018), and turnover rates remain low due to the high cost of housing in the private sector. While the city does acquire existing properties to convert into social housing, the primary way to address the housing crisis has been through new-build social housing, particularly in the already dense northern and eastern arrondissements. ${ }^{3}$ However, with the number of vacant properties appearing to surpass the number of new homes in the $18^{\text {th }}$ arrondissement in recent years, new-build construction may not be the panacea for Paris's housing crisis.

This incredibly dense residential situation is coupled with a relatively low proportion of public green spaces and a network of small, crowded streets with narrow sidewalks (less than two metres wide). Paris has around 14.5 square metres of green space per resident, but this drops to 5.8 square metres when the two large woods on the eastern and western edges of the city are discounted (APUR 2004). This is particularly acute in the aforementioned densely-populated arrondissements where residents may not live within 300 metres of a green space larger than 0.5 hectares, as recommended by the World Health Organization (see APUR 2010; WHO 2016). The Goutte d'Or, for instance, has only 1.3 square metres of green space per inhabitant (APUR 2019). This means that those inhabitants who lack the financial means to choose their place of residence are the most likely to be underserved by Paris's green spaces. Furthermore, in the context of a growing need for housing in the city, the construction

2 France has three types of social housing: PLAI, PLUS and PLS. The income threshold for a PLS apartment for a family of four in Paris is currently $€ 71,016$, while the income thresholds for similar PLAI and PLUS households are $€ 30,521$ and $€ 55,486$, respectively.

3 Although the 2018 Elan law allows the city to requisition properties left vacant for two years and speeds up the construction process for social housing, the full impact of these new regulations on the housing shortage and the extent to which the city will pursue these alternatives will not be known for some time. 
of "green spaces" has increasingly focused on vertical vegetation and creative forms of "green infrastructure" along roads, tram lines, roofs, and walls that improve air quality and aesthetics, but which offer limited spaces for recreation and socializing.

However, since the year 2000 residents have started to work in conjunction with local authorities to create community gardens and other small green spaces throughout the city. These community gardens, known as jardins partagés (shared gardens), are largely concentrated in the working-class neighbourhoods in northern and eastern Paris where green spaces are limited and "bulldozer renovations" have left city-owned lots vacant as they await new construction. A number of these gardens are "nomadic", occupying vacant lots through an agreement with the city and its semi-public developer SEMAVIP - a form of temporary urbanism that requires the gardens embrace mobility in order to survive (Demailly and Darly 2017). While this forced mobility permits the expansion of green spaces in dense neighbourhoods, uprooting and relocating a nomadic garden requires time, organization and a huge physical effort. Moreover, as gardeners become emotionally attached to their gardens and the communities and relationships that grow from them (Eizenberg 2012; Hondagneu-Sotelo 2017), relocating a garden can mean breaking up a community and severing place-based ties that gardeners have developed. Nomadic gardens may improve access to green spaces but they can also exact heavy physical and emotional tolls when required to relocate.

Furthermore, while community gardens may represent an improvement in the quality of life for the gardeners (Demailly 2017), they are implicated in the gentrification frontier sweeping north and east across the city as property prices rise and middle-class residents move in (Clerval 2013; Newman 2011). In areas where new middle-class residents have lobbied for greater investment in their neighbourhoods, new green spaces have been accompanied by arts centres, sports facilities, and the territorial extension of city-wide cultural events (Clerval and Fleury 2009). The appropriation of vacant lots for community gardening by the middle classes has also led to the "invisibilization" of working-class inhabitants, as the gardeners create green spaces on sites where they believe "nothing existed before" (Adam and Mestdagh 2019). Moreover, white middle-class residents have used their involvement in community gardens to strengthen their established positions in these working-class neighbourhoods, exacerbating the social and physical divisions between themselves and poorer, racialized residents (Mestdagh 2016). Although community gardens may increase the amount of green space in Paris's densely-populated areas, not all are equally inclusive or accessible to poorer residents.

In recent years tensions have emerged between the city's construction plans in the Goutte d'Or and residents' growing desire for green and open spaces. As the neighbourhood's last vacant lots are built upon and disappear, some residents have begun to express dissatisfaction with the availability of parks and gardens in the area. The neighbourhood's dense built environment, coupled with a dense residential population, has created a sense of anxiety and disillusion among vocal, middle-class residents, many of whom moved to the working-class area with the promise of increased social mixing and rising property values brought about through renovations. Amongst this section of residents, concerns over residential density and a high provision of social housing remain high, particularly when 
new construction comes at the cost of existing or desired green space. In July 2019, nearly 200 residents and representatives from local associations crowded into the local council for a public meeting about a proposed construction project in the north of the neighbourhood, which would include 500 new apartments (50\% social housing) and a one hectare park. Frustrations with the project were quickly made clear, with attendees citing statistics on the neighbourhood's lack of green spaces and high population density, and questioning why the entire site could not become a park. Labelling these complaints "anti-housing talk", the mayor of the $18^{\text {th }}$ arrondissement, Éric Lejoindre, explained that the current site had "not one square metre of green space" and that the city was instead proposing to create a hectare of green space that both responded to the housing needs of middle-class families in the area and the needs of current and future residents. But following the consultation period, the city reduced the number of family apartments to 400 and increased the green spaces around the proposed development's walkways and roads. While the fight to convert the entire development into a park is ongoing, new-build housing has become a focal point in the struggle for more green spaces. In the section that follows, I will explore the role of a nomadic community garden in the Goutte d'Or and the needs and desires of marginalized and disillusioned inhabitants that are lost or obscured when city planners place housing in opposition to green spaces.

\section{The Goutte Verte}

Since its inception in 2006, the Goutte Verte community garden has continuously operated in the shadow of social housing construction in the Goutte d'Or: its arrival at a new location has been used to distract from the slow renovation process and its departure signalling the imminent construction of new homes. It began as a temporary artistic installation on a vacant lot awaiting social housing construction, and while the first garden lasted only a few months, local residents quickly formed a democratic, membership-based association with a governing board to negotiate with SEMAVIP, the city's developer, for a new placement. As part of the urban renewal agreement, SEMAVIP was required to offer temporary contracts for resident-led participatory initiatives that would "animate" vacant lots and contribute to "social cohesion" in the neighbourhood. As the decades-long renovation of the neighbourhood was marked by frequently long periods between the demolition of one building and the construction of a new one, the formal occupation and "animation" of vacant lots was a way to discourage these areas from becoming dumping grounds while improving the visual and cultural character of an area in transition. Through a series of official contracts over 14 years, the Goutte Verte has occupied seven sites, including a small, sunless permanent garden that was opened in 2017 after the city determined that the location was too unstable for construction. While the garden has gained new members and lost old ones with each move, it has survived not in spite of but rather due to its impermanence, and its existence has been deeply woven into the fabric of housing construction and renovation in the Goutte d'Or.

While the Goutte Verte is a membership-based association, it also seeks to include the local community in the use and management of its nomadic community garden through workshops, open-days, neighbourhood parties, and educational activities for children. 
In 2014, in the midst of the Goutte Verte's largest and longest-lasting garden that grew on a sunny corner lot from 2011 to 2016, the association had upwards of 50 members that spanned socioeconomic lines, generations, and nationalities. In contrast to the homogeneous membership in other community gardens in Paris, many of which are dominated by white middle-class residents (Adam and Mestdagh 2019), the Goutte Verte was diverse. Garden members included retirees, students, social workers, homeless persons, teachers, artists, office workers, manual labourers, landscapers, academics, homeowners, renters, social housing tenants, migrants, and inhabitants born-and-raised in the Goutte d'Or. Of particular note, there was a significant number of gardeners who were unemployed or in insecure, "under-the-table" employment (travail noir) during my fieldwork. For these members, the garden offered a social space, a kitchen to cook their meals, a daily activity to pass the time, a way to meet others and find paid work, and, for a couple of homeless men, an occasional place to sleep during the warmer summer nights.

Most members felt secure in the garden's relationship with the city and SEMAVIP, and board members in particular felt empowered by the role that local associations like the Goutte Verte were given in the area's urban renewal plans. It was the garden's impermanence, however, that was perceived and experienced differently amongst gardeners. Those members who had followed the garden from a previous location - many of whom had held a position on the board at one time or another - embraced mobility and enjoyed the opportunity to meet new people and discover new parts of their neighbourhood with each move. For members that joined the Goutte Verte during its longest occupation, the garden's impermanence increasingly became a source of anxiety as each successive contract neared its end. Many gardeners relished the ability to participate in a creative intervention that gave them the opportunity to appropriate and transform a communal space and lamented that the opportunity would eventually be taken away. Others cherished access to an outdoor area to escape their small apartments. Several members referred to the garden as a "place to breathe" and a "green lung" for the neighbourhood, insinuating that its closure would be suffocating. However, each time the garden's moving date approached, SEMAVIP offered the Goutte Verte another sixmonth extension due to construction delays. With each contract extension, gardeners looked to the struggles and victories of other local campaigns to preserve green spaces in the area against further building densification. ${ }^{4}$ Some gardeners, including board members, became certain that the Goutte Verte's current location would become permanent; others hoped that SEMAVIP would continue extending their contract indefinitely. However, a few members worried that, as SEMAVIP's urban renewal project was nearing completion and the vacant lots were thus disappearing, the Goutte Verte would cease to exist in any form.

Members were acutely aware that the displacement of their garden was needed for SEMAVIP to begin construction on 26 social housing apartments and a new crèche. However, amongst the apartments in the planned building, not one was intended for the lowest-income

4 One such campaign involved a wooded area and community garden called Bois Dormoy. The Bois Dormoy was created by neighbours on an overgrown lot that had been left vacant for 20 years. In 2016 residents won a decade-long battle for protection against the city, which wanted to build an assisted-living facility on the site. 
earners. Instead, the building, like many of the new buildings constructed in the Goutte d'Or in recent years, contained spacious apartments intended for middle-class households and employer-subsidized housing, part of the project of social mixing in the neighbourhood (Bacqué and Fijalkow 2012). The need for more housing in the neighbourhood and in the city as a whole lingered in the background whenever gardeners expressed a desire for more green space or a permanent contract for the Goutte Verte. "It's a pity" was the oft-used expression that followed these comments, as members tried to reconcile their desire for green space with the need for housing. While some gardeners were uncomfortable with the situation and acknowledged that housing should take priority, others were less reserved. In 2015, members circulated a petition asking the Mayor of Paris to intervene and "save" the 300 square meter garden, condemning the "umpteenth real estate development project" in the densely populated neighbourhood. The petition criticized the planned inclusion of subsidized housing for "the lucky employees" of a company who helped finance construction. This was followed by a letter to the Mayor on 27 October 2016 - just weeks before the garden's ultimate relocation - which explained that the Goutte d'Or "suffers greatly from the lack of green spaces", and asked why the city wanted to "destroy one that works well, costs nothing to the community and meets the expectations of the inhabitants?"

When the Goutte Verte was finally relocated as a potted garden on the edge of an outdoor sport field, it was a bittersweet victory. The association had found another temporary home but, as with each relocation, lost members of the community who did not move along with the garden. In the pages that follow I focus on three interlocutors who represent the wide spectrum of Goutte Verte members in terms of socioeconomic positionality, relationship to the neighbourhood, and their use of the garden. These vignettes both highlight the importance of the garden in the everyday lives of its members and point to some of the experiences and communities that are lost when the "voids" of the city are built up and (temporary) green spaces are replaced by housing. In particular, they hint at some of the contradictions that emerge when housing of any calibre is positioned as a blanket social good without taking into account the needs or desires of marginalized residents who might be excluded.

\section{Filip ${ }^{5}$}

Filip was a Serbian national and sans-papiers (lit: without papers) migrant who had lived in eastern Paris since 2003. He worked as a handyman under-the-table for a contractor that hired sans-papiers labourers, but work had become scarce in the years after the 2008 crisis. However, he noted that young French people seemed to spend their days in busy cafés "buying expensive drinks", surmising that "there is no crisis if they can afford that". In 2013 he had been without work for several months and spent his spare time in the Goutte Verte doing construction and repairs. He had built a large two-room cabana in the corner of the garden that contained a kitchen and covered seating area. He built the bookshelves

\footnotetext{
5 Interlocutor names have been changed.
} 
in the cabana that housed a small library of "rescued" books that were donated or found in the rubbish, and he constructed a dining table out of repurposed wood. He also collected items for the garden that other residents had thrown away, including plates, cutlery, chairs, and sculptures that decorated the cabana. He was not involved in the bureaucratic management of the association and any building work he did in the garden was voluntary. However, through his membership he had met other gardeners who hired him for small paid jobs. At the time of our interview, he was doing repairs for two fellow gardeners in their apartments, although these small jobs were not enough to replace his previous employment. Filip explained, "There isn't enough work in general, especially for sans-papiers. The only option is underthe-table work". The garden also served as his kitchen and occasional dormitory when he could not access the small room that he usually rented in the $19^{\text {th }}$ arrondissement. He slept "tranquilly" at night in the garden's cabana, although his use of the kitchen was a point of contention amongst a few other members who accused him of depleting the gas tank to make dinner for himself and his friends. The Goutte Verte was more than just a place to garden - indeed, Filip did not grow anything himself - but rather offered a space that members like Filip, excluded from Parisian spaces of consumption and access to social housing, could remake and repurpose to suit their needs, a place where meeting people might lead to paid work, and a respite from everyday hardships where one could "rest tranquilly".

\section{Sarah}

Sarah, on the other hand, was in the process of purchasing her first home in the north of the neighbourhood before she joined the garden one summer. She had passed the overgrown lot on several occasions before a friend finally pointed out that it was a community garden. "I was shy", she rationalized. "I thought maybe it was some weird little squat thing, with eccentric things". She eventually joined the garden to have access to something that her rented apartment could not offer. She laughed about her initial reasons for joining the Goutte Verte: "After eleven o'clock there was no sun in my [rented] apartment, and I cannot live where there is no sun. So to be very honest the only reason I joined and I started planting was because I needed a space where there is sun". Sarah's motivation for joining the garden was similar to several other gardeners; she wanted a quiet place that offered something her apartment could not. After she purchased a sunny apartment, Sarah came to appreciate the garden as a way to connect her to the neighbourhood socially, emotionally, and physically. Her opinion of the Goutte d'Or changed when she purchased a two-bedroom apartment; she found the area less dangerous, less dirty, and more welcoming. She viewed her purchase as a "social investment" in the neighbourhood and cited the garden as a primary space that made her feel like she belonged. It was through having her own "bit of land" where she could "plant and water" that she came to feel that the neighbourhood had "really positive and exciting energy". However, she explained that she was unlikely to follow the garden to another location if it moved further away but did "not like to think about it". As a new homeowner, Sarah made a place for herself in the Goutte d'Or through gardening (Comstock et al. 2010) and "put down roots" in the neighbourhood. 
Fatima

While Sarah was a relatively new arrival to the neighbourhood living in comfortable accommodation, Fatima was born and raised in the Goutte d'Or and lived alone in a small, crowded studio that overlooked the Goutte Verte. Her elderly mother, Odette, lived in the same building and they would often spend afternoons in the garden relaxing, sharing a meal, and talking with friends while Fatima, who had been unemployed for a few years, tended to her flowers. Fatima lamented the lack of social activities for elderly residents like Odette in the neighbourhood, as most of the activities and associations were geared towards children and teenagers. The garden was one of the only quiet places nearby where mother and daughter could sit and enjoy some fresh air. When the garden first opened on the lot below her apartment, Fatima was concerned that "squatters had arrived", bringing furniture and trash. She quickly became a member, however, and found that the garden's arrival marked an improvement in her daily life. Whereas before there was a large "dilapidated" building blocking direct sunlight and fresh air, and later a vacant lot, the garden opened up the space outside her window with greenery. "It's nice when you are in the garden, it is agreeable. You can see the garden from all the windows [of the building]", she explained. On warm summer evenings she could open her window and smell the fresh herbs and flowers. According to Fatima, the Goutte Verte was "a relaxation area, a place to revitalize yourself... [and] a place to pause". The garden's visibility from her small apartment gave Fatima a sense of space, calmness, and a connection to nature that she previously lacked. For someone who had lived her whole life in the neighbourhood, the community garden was the first time she could see greenery from her window. When the garden's eviction was imminent, Fatima helped mobilize the gardeners and contact local officials to try and save the Goutte Verte or relocate it to a larger vacant lot. However, she expressed concern that she would have nowhere to take her mother when the garden moved further away.

\section{Discussion}

Jardins partagés have become popular in Paris's densely-populated northern and eastern neighbourhoods as a way to bring green spaces and build community bonds in working-class neighbourhoods. While many have reinforced divisions between poorer residents and middleclass gentrifiers (Adam and Mestdagh 2019; Mestdagh 2016), the Goutte Verte offers insight into how these spaces can connect marginalized inhabitants with newer residents through communal gardening. The garden provided a "place to breathe" for a number of its more precarious members, and a chance for disillusioned gardeners to renew their connection to their neighbourhood through nature. As one of the most precarious garden members in terms of his housing and employment situation, Filip found calmness and tranquillity in the garden which was otherwise inaccessible to him elsewhere. He contributed to its appropriation and transformation from a vacant lot to a green oasis in the Goutte d'Or. But the garden also met his basic material and vocational needs, giving him a place to sleep and a kitchen to cook in when he could not rent a room, and bringing him into contact with people who could pay for his services as a handyman. For Fatima and Odette, the garden fulfilled their social and psychological needs: the Goutte Verte gave them an accessible space 
where they could "revitalize" themselves, spend time together and with friends, take in fresh air, and "pause" both physically and mentally. The garden also gave them a view from their windows and kept the space open enough for sunlight to enter their apartments, something that could be sought out by more affluent gardeners like Sarah, but which had long been inaccessible to Fatima and Odette. While the Goutte Verte satisfied an aspirational longing for green space, particularly for those like Sarah who were employed full-time and in stable, comfortable accommodation, it also met the basic needs of a few members like Filip, even if that was not the garden's primary objective.

However, as the city fills in the last of the "voids" of the Goutte d'Or, where inhabitants could appropriate, create, and re-imagine the city according to their needs and desires, the importance of participatory green spaces for people like Fatima, Filip and Sarah is often ignored. While the city's housing plans focus on new-build accommodation intended to socially mix the Goutte d'Or, the city also encourages the participation of local inhabitants through engagement with its developer SEMAVIP, which has opened vacant lots to self-managed community initiatives. But this participatory framework is restrictive and false; marginalized or disillusioned residents are invited to temporarily appropriate spaces of the city as long as they conform to the institutional and bureaucratic requirements laid out by the city and SEMAVIP. By accepting SEMAVIP's terms of temporary participation, associations and inhabitants are left with little room for challenging development plans or proposing longlasting alternatives that might better respond to the needs and desires of residents. In the best case, marginalized and alienated inhabitants have been given the opportunity to temporarily increase green spaces in the densely populated Goutte d'Or and reconnect to their neighbourhood and community through nature. However, these temporary appropriations have also raised expectations and created false hope that permanent improvements could be achieved through what on the surface appears to be a ground-up initiative. Participation and self-management are thus a conditional gesture granted to residents, and by incorporating them into its development plans, city planners remove opportunities for inhabitants to fully participate in the city as oeuvre.

As the city pursues new-build accommodation as the primary solution to the housing crisis, the frustration with a lack of green spaces and artificial, top-down participatory frameworks is becoming more visible. Much like in New York City in the 1990s, Paris urban planners juxtapose the desire for community gardens and green spaces in opposition to housing needs, co-opting social housing to justify further densification. But in so doing, marginalized inhabitants, some of whom are in precarious or crowded housing situations, are excluded. Housing developments may be intended for future residents who are more financially secure than current inhabitants and may reduce access to green spaces for those poorer residents who stand to benefit most from them. While creative appropriations of urban space can socially, physically, psychologically and even economically improve the lives of both marginalized and alienated inhabitants, this becomes obscured by housing-versusgreen space political discourse. Furthermore, attempts to challenge these top-down plans risk being viewed as or becoming "anti-housing", particularly when open land is scarce. Thus, while community gardens like the Goutte Verte offer a material alternative to top-down urbanism that fails to account for a "place to breathe" in densely-populated working-class 
neighbourhoods, their influence is temporary and conditional. In a city like Paris, where the cost of living is increasingly unaffordable for poor and middle-class residents alike, an emphasis on new-build construction as the primary solution to the housing crisis when the number of vacant properties is growing creates a political impasse - one that reduces the conception of the rights to urban life as the simple access to the centre and services rather than the right to transform and be transformed by the city.

\section{References}

Adam, Matthieu and Léa Mestdagh. 2019. “Invisibiliser pour dominer. L'effacement des classes populaires dans l'urbanisme contemporain [Making the Poor Invisible. How Contemporary Urban Planning Erases Lower Classes' Presence]." Territoire en movement: revue de géographie et aménagement/ Territory in Movement: Journal of Geography and Planning 43.

APUR. 2004. Développer le végétal à Paris: les nouvelles règles du plan local d'urbanisme de Paris. Paris: Atelier Parisien d'Urbanisme.

APUR. 2010. Situation et perspectives de la place de la nature à Paris. Rapport d'étape. Paris: Atelier Parisien d'Urbanisme.

APUR. 2019. Les quartiers de la Politique de la ville du 18e arrondissement: évaluation à mi-parcours du contrat de ville de Paris 2015-2020. Paris: Atelier Parisien d'Urbanisme.

Attoh, Kafui A. 2011. "What Kind of Right is the Right to the City?" Progress in Human Geography 35(5): 669-685.

Bacqué, Marie-Hélène and Yankel Fijalkow. 2012. "Social Mix as the Aim of a Controlled Gentrification Process: The Example of the Goutte d'Or District in Paris." Pp. 115-132 in Mixed Communities: Gentrification by Stealth?, edited by Gary Bridge, Tim Butler, and Loretta Lees. Bristol: Policy Press.

Barbosa, Olga, Jamie A. Tratalos, Paul R. Armsworth, Richard G. Davies, Richard A. Fuller, Pat Johnson, and Kevin J. Gaston. 2007. "Who Benefits from Access to Green Space? A Case Study from Sheffield, UK." Landscape and Urban Planning 83(2): 187-195.

Boellstorff, Tom, Bonnie Nardi, Celia Pearce, and T.L. Taylor. 2012. Ethnography and Virtual Worlds: A Handbook of Method. Princeton: Princeton University Press.

Blokland, Talja, Christine Hentschel, Andrej Holm, Henrik Lebuhn, and Talia Margalit. 2015. "Urban Citizenship and Right to the City: The Fragmentation of Claims." International Journal of Urban and Regional Research 39(4): 655-665.

Butler, Chris. 2012. Henri Lefebvre: Spatial Politics, Everyday Life and the Right to the City. Abingdon: Routledge.

Chaskin, Robert J. and Mark L. Joseph. 2013. "'Positive' Gentrification, Social Control and the 'Right to the City' in Mixed-Income Communities: Uses and Expectations of Space and Place." International Journal of Urban and Regional Research 37(2): 480-502.

Classens, Michael. 2015. "The Nature of Urban Gardens: Toward a Political Ecology of Urban Agriculture." Agriculture and Human Values 32(2): 229-239.

Clerval, Anne. 2013. Paris sans le peuple: la gentrification de la capitale. Paris: Éditions La Découverte.

Clerval, Anne and Antoine Fleury. 2009. "Politiques urbaines et gentrification, une analyse critique à partir du cas de Paris [Urban Policies and Gentrification, a Critical Analysis Based on the Case of Paris]." L'Espace Politique 8(2).

Comstock, Nicole, L. Miriam Dickinson, Julie A. Marshall, Mah-J. Soobader, Mark S. Turbin, Michael Buchenau, and Jill S. Litt. 2010. "Neighborhood Attachment and its Correlates: Exploring 
Neighborhood Conditions, Collective Efficacy, and Gardening." Journal of Environmental Psychology 30(4): 435-442.

Cupers, Kenny. 2014. The Social Project: Housing Postwar France. Minneapolis: University of Minnesota Press.

Demailly, Kaduna-Eve. 2014. "Les jardins partagés de l'est parisien: de nouveaux territoires citoyens?" Pp. 193-204 in Les jardins dans la ville entre nature et culture, edited by M.-J. Menozzi. Rennes: Presses Universitaires de Rennes.

Demailly, Kaduna-Eve. 2017. "Les jardins partagés franciliens: des territoires de transition environnementale? [The Shared Gardens of the Île-de-France Region: Environmental Transition Territories?]" Géographie et cultures 101: 79-96.

Demailly, Kaduna-Eve and Ségolène Darly. 2017. "Urban Agriculture on the Move in Paris: The Routes of Temporary Gardening in the Neoliberal City." ACME: An International E-Journal for Critical Geographies 16(2): 332-361.

Donzelot, Jacques. 2003. Faire société: La politique de la ville aux Etats-Unis et en France. Paris: Le Seuil.

Duke, Joanna. 2009. "Mixed Income Housing Policy and Public Housing Residents' 'Right to the City'." Critical Social Policy 29(1): 100-120.

Eizenberg, Efrat. 2012. "Actually Existing Commons: Three Moments of Space of Community Gardens in New York City.” Antipode 44(3): 764-782.

Eizenberg, Efrat. 2013. From the Ground Up: Community Gardens in New York City and the Politics of Spatial Transformation. Farnham: Ashgate Publishing, Ltd.

EUROSTAT. 2016. Urban Europe: Statistics on Cities, Towns and Suburbs. Luxembourg: Publications office of the European Union.

Fijalkow, Yankel. 2013. "Sociologie des villes, sociologie du logement. Des complémentarités à refonder à la lumière du processus de gentrification [Sociology of Cities, Housing Sociology Building Complementarities to Inform Gentrification Process]." Sociologie et sociétés 45(2): 177-194.

Harvey, David. 2008. "The Right to the City." New Left Review 53: 23-40.

Harvey, David. 2012. Rebel Cities: From the Right to the City to the Urban Revolution. London: Verso Books.

Hondagneu-Sotelo, Pierrette. 2017. “At Home in Inner-City Immigrant Community Gardens.” Journal of the Built Environment 32: 13-28.

INSEE. 2019. Dossier complet: commune de Paris 18e arrondissement (75118). Paris: Institut national de la statistique et des études économiques.

Lefebvre, Henri. 1976. The Survival of Capitalism: Reproduction of the Relations of Production. London: Allison \& Busby.

Lefebvre, Henri. 2000. Writings on Cities. Reprint edition. Cambridge, Mass, USA: Blackwell Publishers.

Lefebvre, Henri. 2003. Key Writings. Edited by Stuart Elden, Elizabeth Lebas, and Eleonore Kofman. London: Bloomsbury.

Mancebo, François. 2015. "Combining Sustainability and Social Justice in the Paris Metropolitan Region." Pp. 263-284 in Sustainability in the Global City: Myth and Practice, edited by C. Isenhour, G. McDonogh, and M. Checker. New York: Cambridge University Press.

Marcuse, Peter. 2012. "Whose Right(s) to What City?" Pp. 24-41 in Cities for People, Not for Profit: Critical Urban Theory and the Right to the City, edited by N. Brenner, P. Marcuse, and M. Mayer. Routledge.

McCann, Eugene J. 2002. "Space, Citizenship, and the Right to the City: A Brief Overview." GeoJournal 58: 77-79.

Mestdagh, Léa. 2016. “Construire un réseau de quartier: quand le collectif jardinier imprègne les sociabilités locales. Deux exemples parisiens [Building a Neighborhood Network: When the Shared 
Garden Group Impacts Local Social Relations. Two Parisian Examples].” Lien social et Politiques (77): 166-183.

Mitchell, Don. 2003. The Right to the City: Social Justice and the Fight for Public Space. New York: Guilford Press.

Newman, Andrew. 2011. "Contested Ecologies: Environmental Activism and Urban Space in Immigrant Paris." City \& Society 23(2): 192-209.

OLS. 2018. Données repères: le parc locatif social et son occupation en Île-de-France. Paris: Observatoire de du logement social.

Pierce, Joseph, Olivia R. Williams, and Deborah G. Martin. 2016. "Rights in Places: An Analytical Extension of the Right to the City." Geoforum 70: 79-88.

Purcell, Mark. 2003. "Citizenship and the Right to the Global City: Reimagining the Capitalist World Order." International Journal of Urban and Regional Research 27(3): 564-590.

Purcell, Mark. 2006. "Urban Democracy and the Local Trap.” Urban Studies 43(11): 1921-1941.

Purcell, Mark. 2014. "Possible Worlds: Henri Lefebvre and the Right to the City." Journal of Urban Affairs 36(1): 141-154

Purcell, Mark and Shannon K. Tyman. 2015. "Cultivating Food as a Right to the City." Local Environment 20(10): 1132-1147.

Schmelzkopf, Karen. 1995. "Urban Community Gardens as Contested Space." Geographical Review 85(3): 364-381.

Shillington, Laura J. 2013. "Right to Food, Right to the City: Household Urban Agriculture, and Socionatural Metabolism in Managua, Nicaragua." Geoforum 44: 103-111.

Smith, Christopher and Hilda E. Kurtz. 2003. "Community Gardens and Politics of Scale in New York City.” Geographical Review 93(2): 193-212.

Staeheli, Lynn A., Don Mitchell, and Kristina Gibson. 2002. "Conflicting Rights to the City in New York’s Community Gardens.” GeoJournal 58(2): 197-205.

Uitermark, Justus, Walter Nicholls, and Maarten Loopmans. 2012. "Cities and Social Movements: Theorizing beyond the Right to the City." Environment and Planning A 44: 2546-2554.

Ward Thompson, Catherine. 2012. "Places to Be Wild in Nature." Pp. 49-64 in Urban Wildscapes, edited by A. Jorgensen and R. Keenan. London: Routledge.

WHO. 2016. Urban Green Spaces and Health. Copenhagen: World Health Organization.

Wolch, Jennifer R., Jason Byrne, and Joshua P. Newell. 2014. "Urban Green Space, Public Health, and Environmental Justice: The Challenge of Making Cities 'Just Green Enough." Landscape and Urban Planning 125: 234-244.

Yiftachel, Oren. 2015. “Epilogue_From 'Gray Space' to Equal 'Metrozenship'? Reflections on Urban Citizenship.” International Journal of Urban and Regional Research 39(4): 726-737.

\section{Author}

Carrie Ann Benjamin is a Leverhulme Early Career Fellow in the Department of Sociology at the University of Warwick. She is an ethnographer and urban anthropologist interested in the role of public space in reshaping local and national debates on inequality, immigration and "race" in France.

Contact: carrie.benjamin@warwick.ac.uk 